\title{
Blocking N-Cadherin Function Disrupts the Epithelial Structure of Differentiating Neural Tissue in the Embryonic Chicken Brain
}

\author{
Susanne I. I. Gänzler-Odenthal, ${ }^{1,2}$ and Christoph Redies ${ }^{1,2,3}$ \\ 1/nstitute of Biology III, University of Freiburg, D-79104 Freiburg, Germany, ${ }^{2}$ Department of Biochemistry, Max Planck- \\ Institute of Developmental Biology, D-72072 Tübingen, Germany, and 3/nstitute of Anatomy, University Hospital Essen, \\ D-45122 Essen, Germany
}

The cell adhesion molecule $\mathrm{N}$-cadherin is ubiquitously expressed in the early neuroepithelium, with strongest expression in the ependymal lining. We blocked the function of $\mathrm{N}$-cadherin during early chicken brain development by injecting antibodies against $\mathrm{N}$-cadherin into the tectal ventricle of embryos at 4-5 d of incubation [embryonic day 4 (E4)-E5]. N-cadherin blockage results in massive morphological changes in restricted brain regions. At approximately $\mathrm{E} 6$, these changes consist of invaginations of pieces of the ependymal lining and the formation of neuroepithelial rosettes. The rosettes are composed of central fragments of ependymal lining, surrounded by an inner ventricular layer and an outer mantle layer. Radial glia processes are radially arranged around the ependymal centers of the rosettes. The normal layering of the neural tissue is thus preserved, but its coherent epithelial structure is disrupted. The observed morphological changes are restricted to specific brain regions such as the tectum and the dorsal thalamus, whereas the ventral thalamus and the pretectum are almost undisturbed. At E10-E11, analysis of late effects of $\mathrm{N}$-cadherin blockage reveals that in the dorsal thalamus, gray matter is fragmented and disorganized; in the tectum, additional layers have formed at the ventricular surface. Together, these results indicate that $\mathrm{N}$-cadherin function is required for the maintenance of a coherent sheet of neuroepithelium in specific brain regions. Disruption of this sheet results in an abnormal morphogenesis of brain gray matter.

Key words: cell adhesion; cadherin; morphogenesis; brain nucleus formation; diencephalon; tectum; brain segments; chicken embryo
Over a dozen cadherins are expressed in the nervous system. Each cadherin is expressed in a regionally restricted pattern from the onset of expression (Redies and Takeichi, 1996). An exception is N-cadherin, which is expressed throughout the early neuroepithelium, with strongest expression in the ependymal (ventricular) lining. Here, N-cadherin is associated with the adherens junctions between the neuroepithelial cells and their processes lining the ventricle (Hatta and Takeichi, 1986; Volk and Geiger, 1986; Aaku-Saraste et al., 1996).

$\mathrm{N}$-cadherin is expressed from the beginning of the neural tube formation (Crossin et al., 1985; Hatta and Takeichi, 1986; Duband et al., 1988) and remains expressed in the neuroepithelium (proliferative) (Redies and Takeichi, 1993; Gänzler and Redies, 1995). In the developing mantle layer, N-cadherin becomes restricted to a subset of brain nuclei and fiber tracts that, later in development, form specific parts of functional systems (Redies and Takeichi, 1993; Redies et al., 1993). N-cadherin has been found also in the synaptic complex (Yamagata et al., 1995; Fannon and Colman, 1996; Uchida et al., 1996).

Several studies investigated the function of N-cadherin in different species. In Xenopus, ectopic misexpression of N-cadherin

\footnotetext{
Received Feb. 2, 1998; revised April 8, 1998; accepted April 29, 1998.

This work was supported by grants from the Neurobiology Programme of the Land Baden-Württemberg and the Max Planck-Society. We thank M. Takeichi for cadherin antibodies and cDNAs, M. Itoh for T8-754 antibody, U. Dräger for R5 antibody, E. de la Rosa for antibodies against Ng-CAM/G4, G. Chapman for Gbx-2 cDNA, M. Ast and A. Herzfeld for technical assistance, U. Schwarz for generous support, and K. Arndt and J. C. P. Wöhrn for neuroanatomical suggestions.

Correspondence should be addressed to C. Redies, Institute of Anatomy, University Hospital Essen, Hufelandstrasse 55, D-45122 Essen, Germany.

Copyright (C) 1998 Society for Neuroscience $\quad 0270-6474 / 98 / 185415-11 \$ 05.00 / 0$
}

in early embryos results in perturbed histogenesis of the neural tube (Detrick et al., 1990; Fujimori et al., 1990). In zebra fish, misexpression of $\mathrm{N}$-cadherin causes a distortion of embryos (Bitzur et al., 1994). Transgenic mice lacking N-cadherin function show severe deficits in early heart development and undulated neural tubes. Homozygous embryos are viable only until day 10 of gestation, corresponding to very early stages of neural tube differentiation (Radice et al., 1997). In vivo application of functionally blocking antibodies against $\mathrm{N}$-cadherin results in undulated neural tubes when antibodies are applied early in development (Bronner-Fraser et al., 1992; Nakagawa and Takeichi, 1997). In cultures of chicken retina, $\mathrm{N}$-cadherin blockage causes the formation of rosettes of neural tissue at early stages of development, whereas at later stages no such changes were observed (Matsunaga et al., 1988b). Several studies demonstrated a direct role of $\mathrm{N}$-cadherin in neuronal migration, axon outgrowth, axonal pathfinding, and target recognition, both in vitro (Bixby et al., 1988; Matsunaga et al., 1988a; Tomaselli et al., 1988; Bixby and Zhang, 1990) and in vivo (Barami et al., 1994; Riehl et al., 1996; Stone and Sakaguchi, 1996; Inoue and Sanes, 1997; Iwai et al., 1997).

In the present study, we investigate the morphogenetic function of N-cadherin during early chicken brain development by injecting a functionally blocking rat monoclonal antibody directed against the binding region of this molecule. This antibody, NCD-2 (Hatta and Takeichi, 1986), was injected into the tectal ventricle at 4-5 d of incubation [embryonic day 4 (E4)-E5]. Morphological changes were induced in restricted brain regions, e.g., the tectum and the dorsal thalamus. In these brain regions, an invagination of the ependymal lining was observed, resulting in the formation of small spherical fragments of neural tissue (rosettes). We also 
describe the effect of these early morphological changes on the later development of brain gray matter structures.

This work has been published in preliminary form (Gänzler and Redies, 1996).

\section{MATERIALS AND METHODS}

Animals and antibodies. Fertilized Hisex chicken eggs (Gallus domesticus) were obtained from a local farm and incubated at $37^{\circ} \mathrm{C}$ and $65 \%$ humidity in a forced-draft incubator. Staging of the embryos was according to Hamburger and Hamilton (1951). Embryos of 3-11 d of incubation (E3-E11) were used.

To block the function of $\mathrm{N}$-cadherin, the following antibodies were used: rat monoclonal antibody NCD-2 against chicken N-cadherin (a kind gift from M. Takeichi, Kyoto University, Kyoto, Japan) (Hatta and Takeichi, 1986) and NCD-2 Fab fragments. In preliminary experiments, a polyclonal rabbit antiserum against $\mathrm{N}$-cadherin (Hatta et al., 1988) was also used (a kind gift from M. Takeichi). Rat IgG (ChromPure; Dianova, Hamburg, Germany) and NCD-2 Fc fragments served as a control.

For immunohistochemistry, the following antibodies against cadherins were used: rat monoclonal antibody NCD-2 and a rabbit polyclonal antiserum against chicken $\mathrm{N}$-cadherin (affinity purified by protein $\mathrm{A}$ ); mouse monoclonal antibody RCD-2 against chicken R-cadherin (Redies et al., 1992); and mouse monoclonal antibody CC7-1 raised against chicken cadherin-7 (S. Nakagawa and M. Takeichi, unpublished observations) (kind gifts from $\mathrm{M}$. Takeichi). Mouse monoclonal antibody $1 \mathrm{E} 12$ or a rabbit polyclonal antiserum against $\mathrm{Ng}-\mathrm{CAM} / 8 \mathrm{D} 9 / \mathrm{G} 4$ (a kind gift from E. de la Rosa, Cajal Institute, Madrid, Spain) (de la Rosa et al., 1990) were used to detect most early postmitotic neurons and their processes. Radial glia was visualized by mouse monoclonal antibody R5 raised against a vimentin-associated protein in radial glia (a kind gift from U. Dräger, Eunice Kennedy Shriver Center, Waltham, MA) (Dräger et al., 1984; Vanselow et al., 1989; Herman et al., 1993). To detect proliferating cells, a mouse monoclonal antibody against bromodeoxyuridine (BrdU) (Bioscience Products) was used. As a marker of the ependymal (ventricular) lining (Aaku-Saraste et al., 1996), mouse monoclonal antibody T8-754 against ZO-1, a membrane-peripheral protein of tight junctions, was used (a kind gift from M. Itoh, Kyoto University) (Itoh et al., 1991, 1993). To visualize axonin-1-expressing fibers in the tectum, monoclonal mouse antibody $23.4-5$ generated by T. M. Jessell and J. Dodd was obtained from the Developmental Studies Hybridoma Bank (maintained by the Department of Pharmacology and Molecular Sciences, Johns Hopkins University School of Medicine, Baltimore, MD, and the Department of Biology, University of Iowa, Iowa City, IA, under contract NO1-HD-2-3144 from the National Institute of Child Health and Human Development). Appropriate secondary antibodies labeled with DTAF, Cy3, or biotin were obtained from Dianova. To minimize cross-reactivity with rat antibodies injected into the brain, mouse and rabbit primary antibodies used for immunostaining were detected by secondary antibodies affinity-purified against rat IgG.

Production of NCD-2 Fab fragments. IgG from supernatant of NCD-2 hybridoma cells was purified over a protein G column (Pharmacia, Freiburg, Germany), concentrated (Centricon 30 plus concentrators; Amicon, Beverly, MA), and extensively dialyzed against $20 \mathrm{~mm}$ phosphate buffer-10 mm EDTA, $\mathrm{pH}$ 7.0. Papain digestion was performed with immobilized papain (Pierce, Rockford, IL) as described by the manufacturer. Digestion was performed overnight with $0.5 \mathrm{ml}$ of $\sim 2 \mathrm{mg} / \mathrm{ml}$ NCD-2 IgG solution. The Fab fragments were separated from the Fc fragments by a protein G-Sepharose 4 fast flow column (Pharmacia). Preliminary experiments showed that in the case of the rat antibody NCD-2, the protein G column binds the Fab fragments. The Fab fragments were eluted from the column with $0.1 \mathrm{M}$ glycine, $\mathrm{pH}$ 2.5. The Fab and $\mathrm{Fc}$ fragments were separately concentrated (Centricon 30 concentrators, Amicon) and extensively dialyzed against HBSS, $\mathrm{pH}$ 7.4.

Shell-less cultures. Shell-less cultures of chicken embryos were obtained as described by Auerbach et al. (1974) and modified as described by Thanos and Bonhoeffer (1983). The contents of fertilized E3 eggs were transferred to humidified $20 \times 100 \mathrm{~mm}$ Petri dishes (Greiner, Frickenhausen, Germany) and incubated at $37^{\circ} \mathrm{C}$ for the duration of the experiment.

Antibody injection. NCD-2 (2.5 $\mu \mathrm{g} / \mu \mathrm{l}$ solution; eight embryos), NCD-2 Fab fragments $(0.7 \mu \mathrm{g} / \mu \mathrm{l}$ solution; three embryos), NCD-2 Fc fragments $(0.5 \mu \mathrm{g} / \mu \mathrm{l}$ solution; three embryos), and control rat $\operatorname{IgG}(8-10 \mu \mathrm{g} / \mu \mathrm{l}$ solution; five embryos) were injected through the tectal wall into the tectal ventricle. All solutions were dialyzed extensively against HBSS.
Each embryo was injected twice, once at E4 and once at E5, with 5 and $9 \mu \mathrm{l}$ of solution, respectively. In preliminary experiments, 3 and $5 \mu \mathrm{l}$, respectively, of a polyclonal $\mathrm{N}$-cadherin antiserum was injected. Embryos were fixed $45-50 \mathrm{hr}$ after the first injection. One hour before fixation, embryos were injected with $5 \mu \mathrm{l}$ of a $50 \mathrm{~mm}$ solution of BrdU in HBSS into the tectal ventricle.

To assess late morphological changes observed after injection of functionally blocking antibody, four embryos were injected with NCD-2 antibody, and four embryos were injected with control rat IgG, as described above. The embryos were fixed at E11, but because of the culture conditions the embryos had only developed up to a stage corresponding to approximately E10.5 of normal development.

To study the time course of the early morphological changes, $5 \mu \mathrm{l}$ of NCD-2 was injected at E4, and embryos were fixed 4, 8, 12, 16, 20, and $24 \mathrm{hr}$ after injection. For each time point, two to three embryos were analyzed.

Fixation and immunohistochemical procedures. The heads of the embryos were fixed in $4 \%$ formaldehyde in HBSS supplemented with $1 \mathrm{mM}$ $\mathrm{Ca}^{2+}$ and $1 \mathrm{mM} \mathrm{Mg}^{2+}$ (HBSS+) for $1-3 \mathrm{hr}$, depending on their size. Subsequently, heads were incubated in a graded series of sucrose solution $(12,15$, and $18 \%$ sucrose in HBSS + ) for 30-60 min each, embedded in Tissue Tek O.C.T. compound (Miles, Elkhart, IN), and frozen in liquid nitrogen.

Sections obtained in a cryostat were post-fixed in $4 \%$ formaldehyde in HBSS + for $10 \mathrm{~min}$ and washed three times in TBS supplemented with 1 $\mathrm{mM} \mathrm{Ca}^{2+}, \mathrm{pH}$ 7.6. Immunostaining procedures were done as described previously (Redies et al., 1992; Gänzler and Redies, 1995). Briefly, sections were incubated with appropriately diluted primary and secondary antibodies. Sections processed for immunofluorescence histochemistry were counterstained with the nuclear dye Hoechst 33258 (Sigma, Deisenhofen, Germany) and embedded in 90\% glycerol-10\% TBS. Some sections from E10-E11 brains were processed for peroxidase immunohistochemistry with a commercially available kit (ABC Elite kit Vector Laboratories), following the manufacturer's instructions. BrdU immunostaining was performed after immunostaining with the polyclonal antiserum against $\mathrm{Ng}-\mathrm{CAM} / 8 \mathrm{D} 9 / \mathrm{G} 4$, following previously published procedures (Gänzler and Redies, 1995).

In situ hybridization. Previously published procedures were followed (Redies et al., 1993; Gänzler and Redies, 1995) for in situ hybridization. Digoxigenin-labeled antisense cRNAs were synthesized using kits from Stratagene (La Jolla, CA) and Boehringer Mannheim (Mannheim, Germany). Probes were alkaline-hydrolyzed into $\sim 300$ bp fragments. The following derivatives of pBluescript DNA vectors containing full-length cDNAs were used: pRcad (chicken R-cadherin; Inuzuka et al., 1991); Z10T6/BS (a kind gift from M. Takeichi) (chicken N-cadherin; Hatta et al., 1988); and a plasmid-containing mouse Gbx-2 cDNA (a kind gift from G. Chapman, University of Adelaide, Adelaide, Australia) (Chapman and Rathjen, 1995). Although Gbx-2 cDNA was derived from mouse, in situ hybridization results in a specific staining pattern in chicken brain. The Gbx-2-labeled structures in chicken brain essentially correspond to those labeled in mouse brain (Redies et al., 1997). In the present study, Gbx-2 was used as a marker for the dorsal thalamic alar plate (Bulfone et al., 1993). Gbx-2 is not expressed in the relatively narrow, most rostral portion of this region in chicken (Redies et al., 1997).

Digoxigenin-labeled RNA was visualized by anti-digoxigenin alkaline phosphatase-conjugated $\mathrm{Fab}$ fragments followed by a coloring reaction using X-phosphate and nitroblue tetrazolium salt as substrates. After dehydration, sections were embedded in Entellan (Merck, Darmstadt, Germany) and viewed and photographed under a transmission light microscope (Axioplan; Zeiss, Oberkochen, Germany) or a binocular microscope (Stemi SV 6; Zeiss).

For anatomical orientation, sections adjacent to those used for immunohistochemistry or in situ hybridization were stained with thionine for Nissl substance, as described previously (Redies et al., 1993).

\section{RESULTS}

In the present study, the function of $\mathrm{N}$-cadherin was blocked between 4 and $6 \mathrm{~d}$ of incubation (E4-E6) by injecting NCD-2 antibody through the tectal wall into the ventricular system of chicken embryos. This injection resulted in prominent morphological changes in the brain, especially in the diencephalon and mesencephalon. NCD-2 Fab fragments and a rabbit antiserum against $\mathrm{N}$-cadherin caused similar effects. An overview of these 


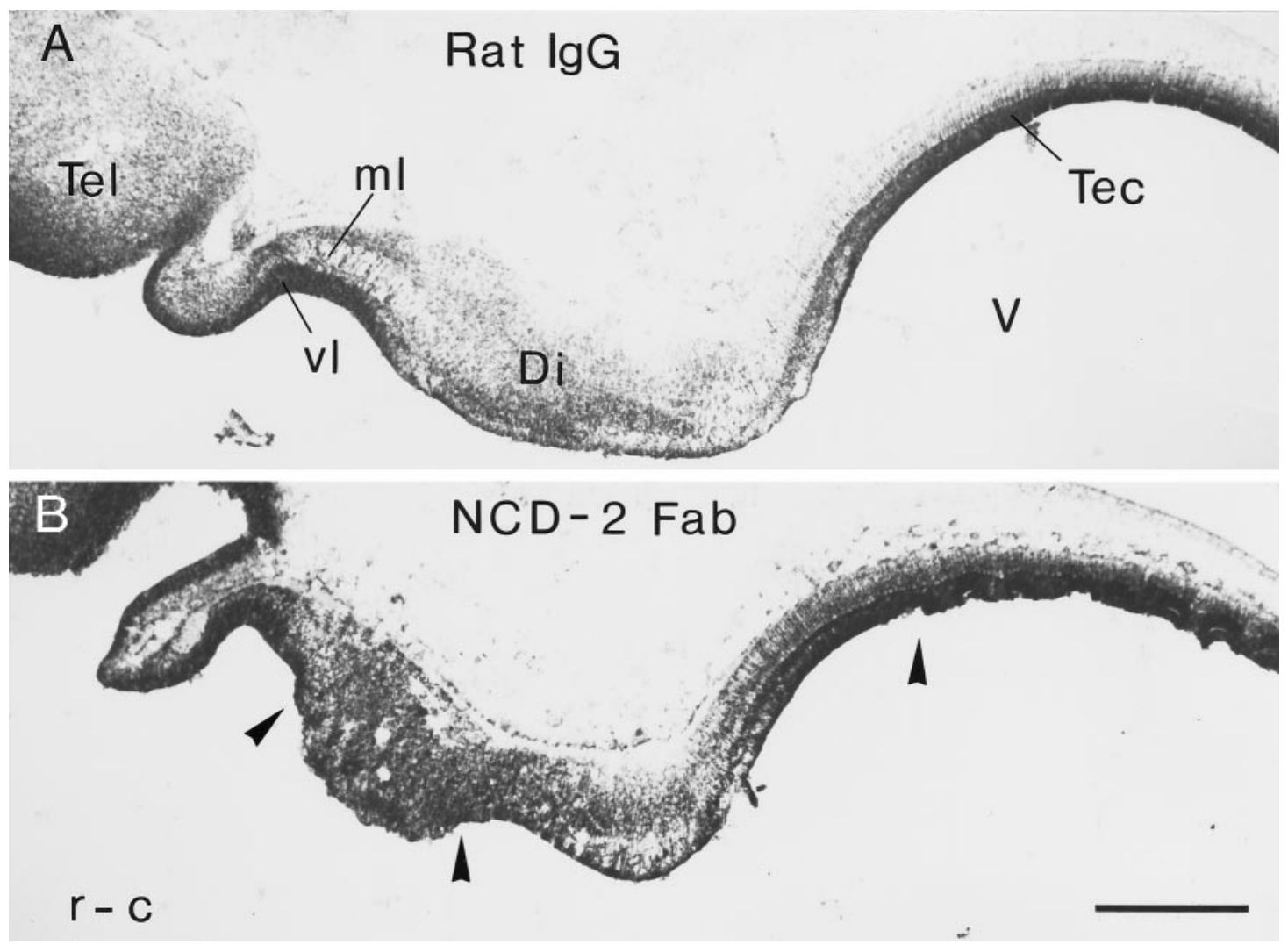

Figure 1. Thionine (Nissl)-stained horizontal cryostat sections from stage 28 embryos treated with control antibodies (12- $\mu \mathrm{m}$-thick section) $(A)$ or with Fab fragments of a monoclonal antibody against N-cadherin (16- $\mu$ m-thick section) $(B)$. Arrowheads in $B$ point to the borders of morphological changes (rosettes) in the diencephalon and in the tectum induced by N-cadherin blockage. $c$, Caudal; $D i$, diencephalon; $m l$, mantle layer; $r$, rostral; Tec, tectum; $T e l$, telencephalon; $V$, ventricle; $v l$, ventricular layer. Scale bar, $0.5 \mathrm{~mm}$.

changes is shown for a Nissl-stained horizontal section in Figure $1 B$. Injection of nonspecific control antibodies or of NCD-2 Fc fragments did not alter the normal morphology of the developing brain (Fig. 1 $A$ ). In each case, injected antibodies or fragments penetrated the entire thickness of the neural tube wall throughout the diencephalon and mesencephalon, as demonstrated by visualizing injected antibodies with appropriately labeled secondary antibodies at approximately E6 (data not shown). Antibody concentrations in brain tissue greatly diminished during further development up to E10-E11 (data not shown).

In many cases, red blood cells were found in the ventricular system. This bleeding may be caused by the blocking of N-cadherin expressed by endothelial cells (Liaw et al., 1990; Salomon et al., 1992; Redies et al., 1993) and was not observed after the control injections. In the diencephalic and mesencephalic tissue itself, pools of blood were not observed, and blood vessels were present (Fig. 2D, small arrows).

\section{Morphological changes induced by $\mathbf{N}$-cadherin blockage}

$\mathrm{N}$-cadherin blockage caused an overall disruption of the layered (epithelial) structure of the neural tube and the formation of rosette-like structures consisting of small pieces of neural tissue. These rosettes fold in from the ventricular surface and partially or completely round up within the neural tube wall. The rosettes were especially prominent and were found consistently in parts of the diencephalon and in the tectum at approximately E6 (Fig. $1 B$ ). Our analysis therefore focused on these regions. The morphological changes were characterized by immunostaining with markers of the ependymal (ventricular) lining (ZO-1), proliferating cells in the ventricular layer (BrdU), early postmitotic neurons in the mantle layer (Ng-CAM/G4), and radial glia (R5). Representative double-label results for the tectum are shown in Figure 2. On the right side of Figure 2, sections from N-cadherinblocked tecta are shown, and control sections are shown on the left side. In addition, $\mathrm{N}$-cadherin protein in the tissue was also visualized by a polyclonal antiserum raised against this molecule. Generally, immunostaining results for sections from brain injected with control antibodies did not differ from untreated brains.

$\mathrm{N}$-cadherin is expressed throughout the neuroepithelium in control tecta but is expressed most prominently by the ependymal lining (Fig. $2 A, e p$ ). In the N-cadherin-blocked tecta, the ependymal lining has disintegrated into pieces, some of which are found inside the E5-E6 tectal wall (Fig. 2C, arrow). The identity of these ependymal remnants was confirmed by double labeling with the ZO-1 antibody (Fig. 2D, arrow). The ependymal remnants form the center of the rosettes. The rosettes have preserved the characteristic layering of the developing neural tube wall with an inner ventricular layer consisting of BrdU-incorporating (proliferative) cells (Fig. $2 H, L$ ) and an outer mantle layer consisting of $\mathrm{Ng}$-CAM/G4-expressing (postmitotic) early neurons and their processes (Fig. 2M). A concentric arrangement of these layers around the remnants of the ependymal lining is also suggested by immunostaining results for the R5 antibody. In normal tecta, radial glia cell bodies are confined to the ventricular layer, and their basal and apical processes span the entire width of the 

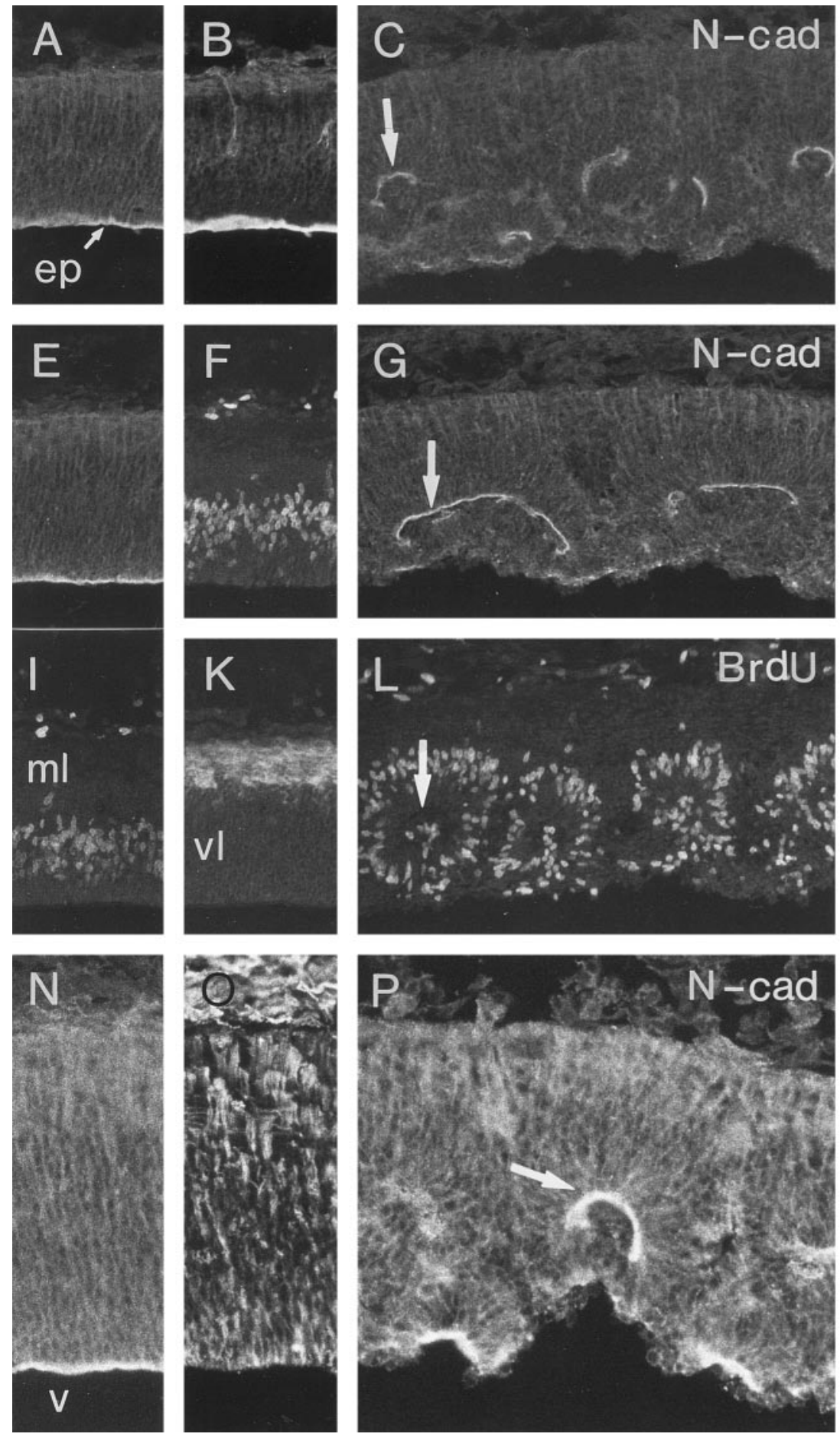
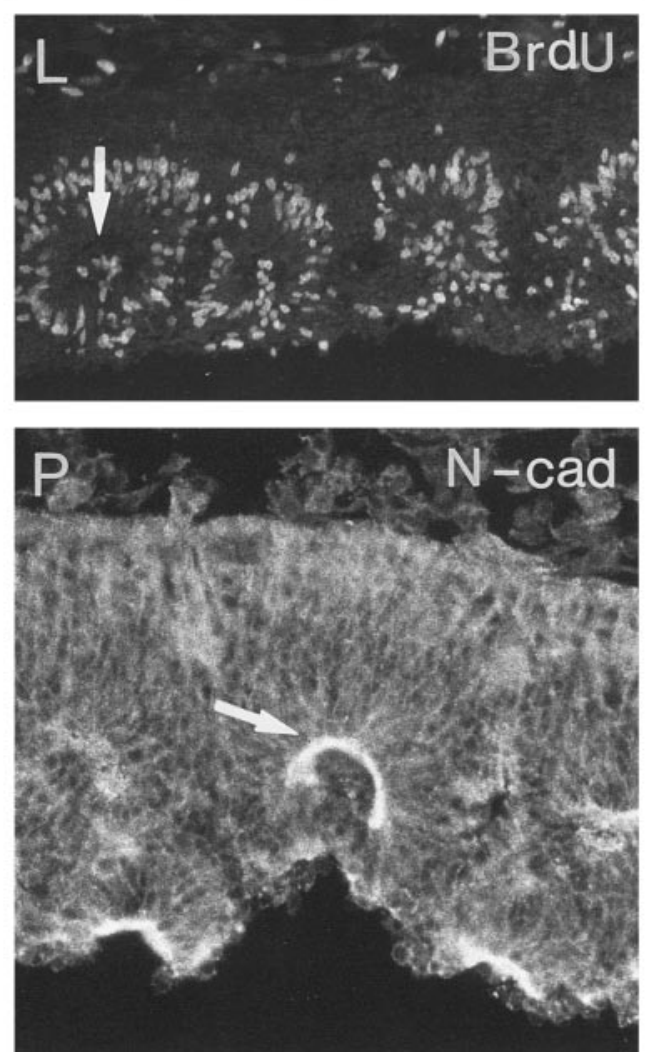
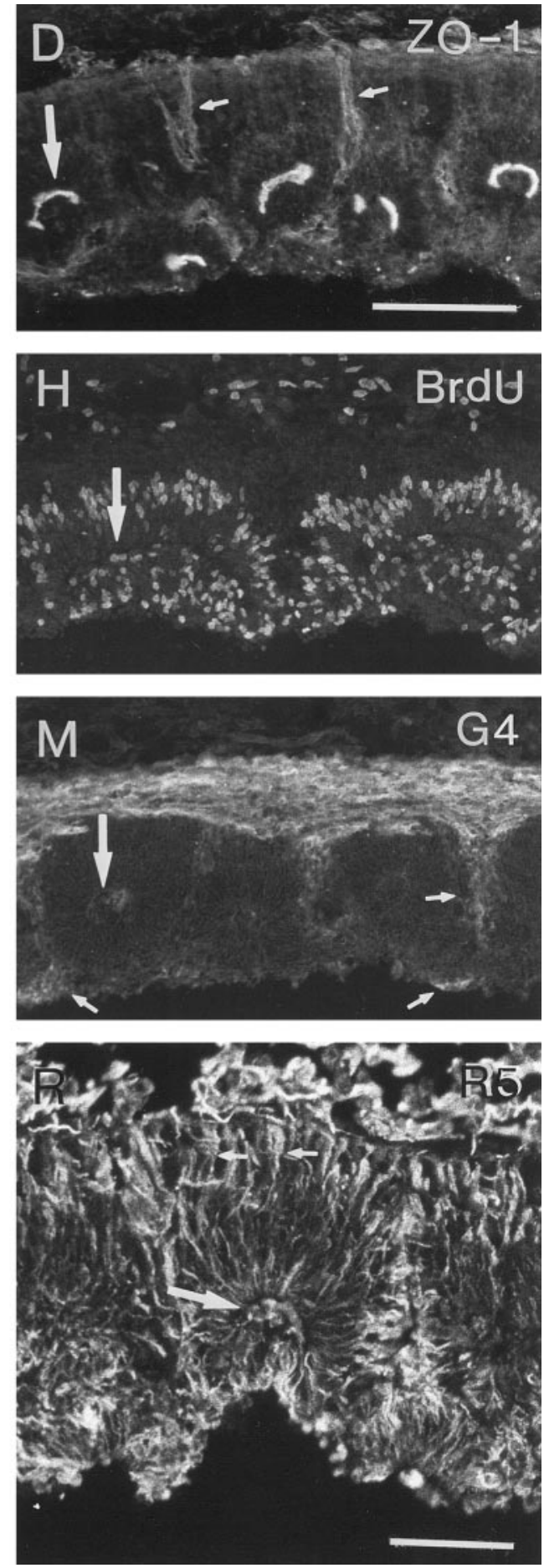

Figure 2. Immunohistochemical characterization of the rosettes. Double-immunostained $12-\mu \mathrm{m}$-thick horizontal sections through the tectum of a stage 28 embryo treated with control rat $\operatorname{IgG}(A, B, E, F, I, K, N, O)$ or with the monoclonal antibody NCD-2 against N-cadherin $(C, D, G, H, L, M, P, R)$. Double-immunostaining results are shown for N-cadherin $(N$-cad; $A, C)$ and ZO-1 $(B, D)$, for N-cadherin $(E, G)$ and bromodeoxyuridine $(B r d U)(F, H)$, for $\operatorname{BrdU}(I, L)$ and $\mathrm{G} 4(K, M)$, and for N-cadherin $(N, P)$ and a radial glia-specific epitope (with the antibody R5) $(O, R)$. Large arrows point to ependymal lining at the center of the rosettes. The small arrow in $A$ points to the ependymal lining (ep). The small arrows in $D$ point to blood vessels that express ZO-1. The small arrows in $M$ point to G4/Ng-CAM-immunoreactive areas in the vicinity of the ventricle. The small arrows in $R$ point to radial glial processes in the mantle layer reaching the pial surface. $m l$, Mantle layer; $v$, ventricle; $v l$, ventricular layer. Scale bars: $D, 0.1 \mathrm{~mm}(A-M) ; R$, $0.05 \mathrm{~mm}(N-R)$.

neural tube from the ventricle to the pial surface (Fig. 2O). In $\mathrm{N}$-cadherin-blocked tecta, the basal radial glial processes converge onto the remnants of the ependymal lining, whereas the apical ones fan out into all radial directions within the rosettes.
Outside the rosettes, the apical processes are more disordered, especially in the vicinity of the ventricle. The apical processes reach the pial surface in a perpendicular orientation (Fig. $2 R$, small arrows). 

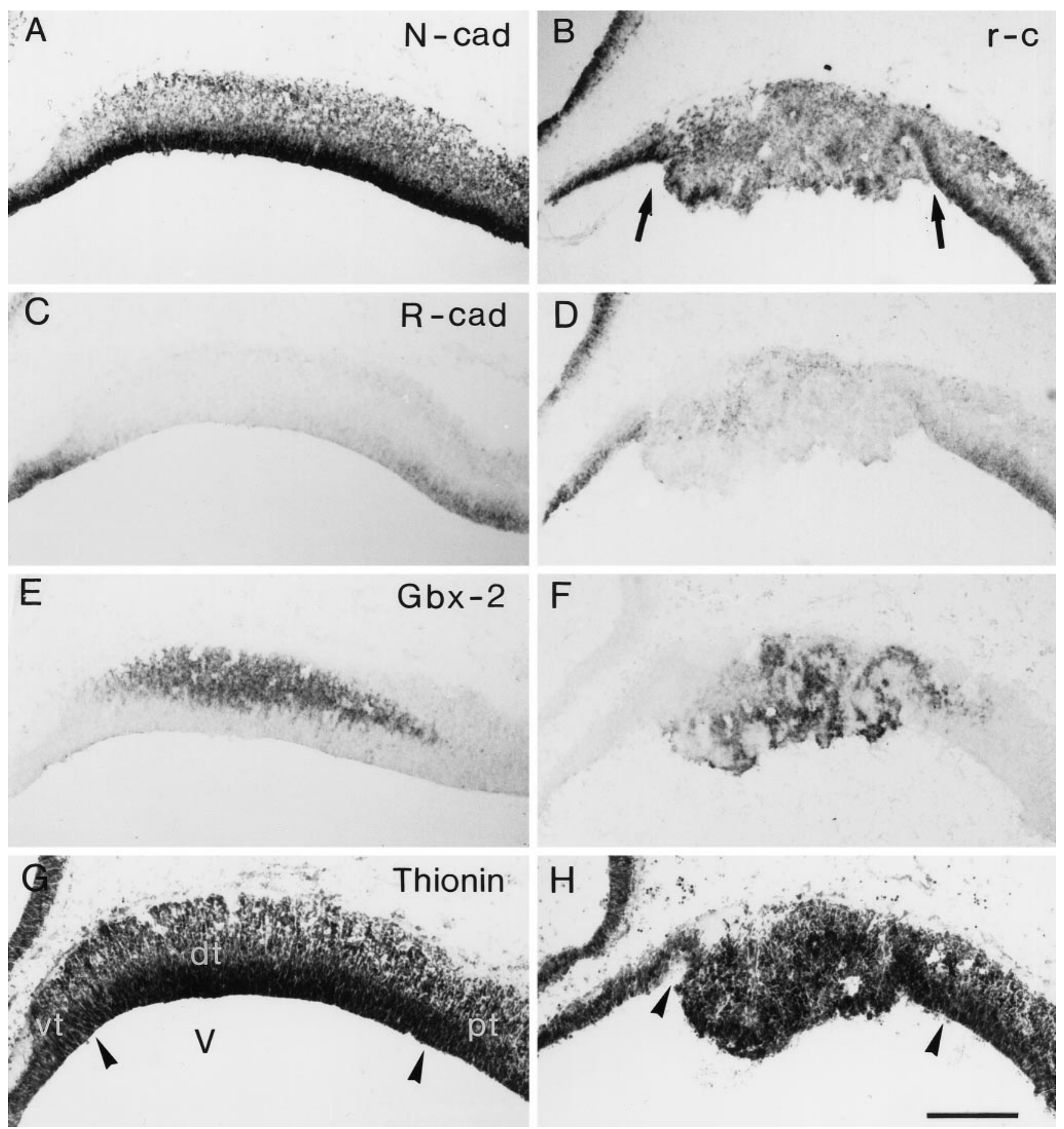

Figure 3. Regional formation of rosettes in the diencephalon. In situ hybridization and thionine (Nissl) staining of 12- $\mu \mathrm{m}$-thick horizontal sections of a stage 28 embryo treated with control rat $\operatorname{IgG}(A, C, E, G)$ or with a monoclonal antibody against N-cadherin $(\mathrm{NCD}-2)(B, D, F, H)$. In situ hybridization results are shown for N-cadherin $(N-c a d ; A, B)$, for R-cadherin $(R$-cad; $C, D)$, for the transcription factor Gbx-2 $(G b x-2 ; E, F)$, and for a thionine stain (Thionin; $G, H$ ). The arrows in $B$ mark the borders of the morphological changes in the dorsal thalamus. Note that only the dorsal thalamus is severely affected. The arrowheads in $G$ and $H$ mark the borders between the ventral thalamus $(v t)$ and the dorsal thalamus $(d t)$ and between the dorsal thalamus and the pretectum ( $p t)$, respectively. $c$, Caudal; $r$, rostral; $V$, ventricle. Scale bar, $0.2 \mathrm{~mm}$.

\section{Regional restriction of morphological changes in the diencephalon}

In the diencephalon, only the dorsal thalamus was severely affected by N-cadherin blockage (Figs. 1, 3), although the injected antibodies diffused into the wall of the entire diencephalon. Minor affected areas were also seen in some regions of the hypothalamus. The identity of the dorsal thalamic region was confirmed by mapping the expression of a marker for this region, Gbx-2 (Fig. $3 E, F$ ). The zona limitans intrathalamica provides an additional marker for the rostral border of this region (Fig. 4, arrowheads). Despite the striking morphological changes in the dorsal thalamus attributable to $\mathrm{N}$-cadherin blockage, this area preserves at least some aspects of its regional identity, as demonstrated by its continued Gbx- 2 expression. Unlike the dorsal 

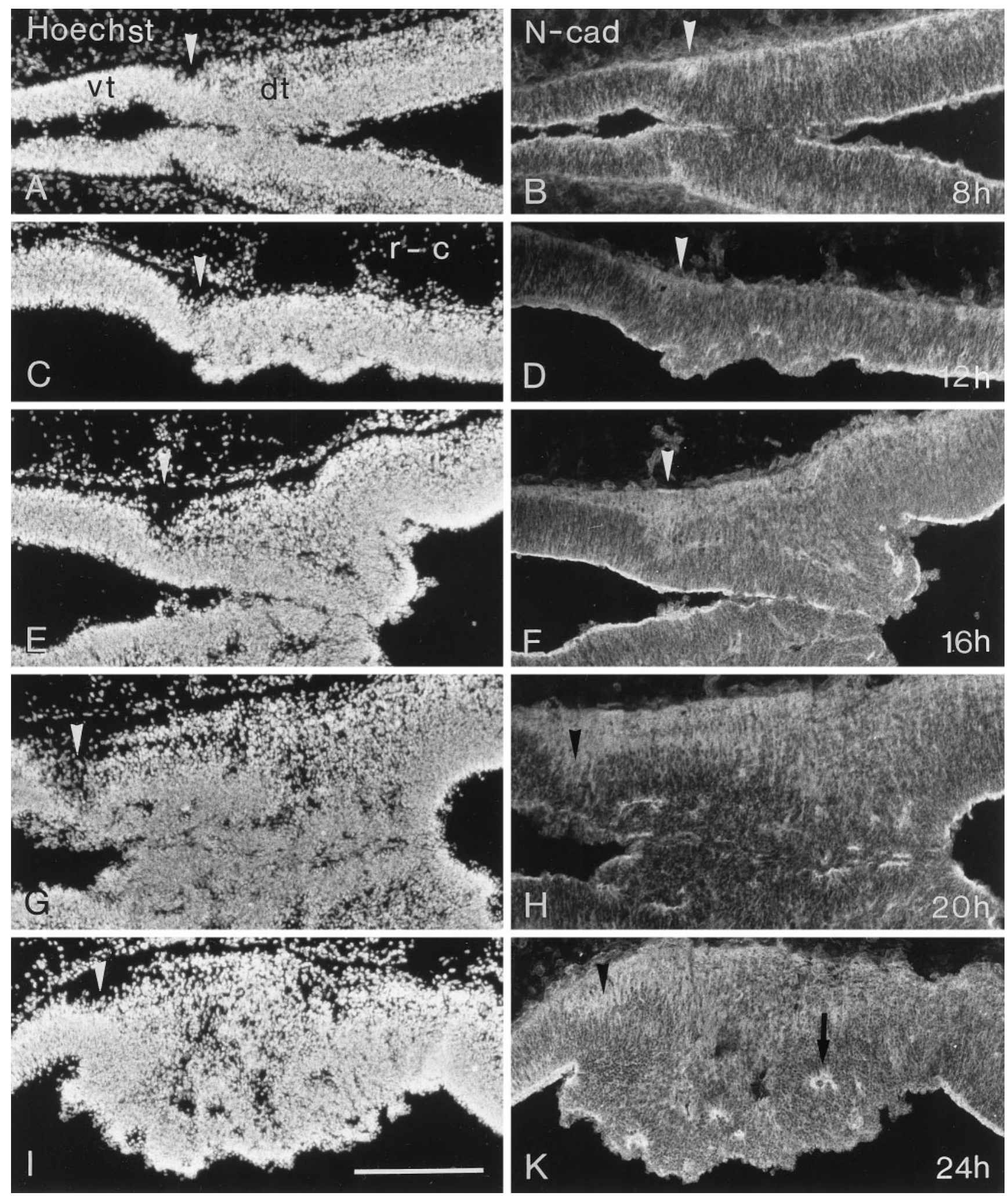

Figure 4. Time course of the rosette formation in the diencephalon. Horizontal $14-\mu \mathrm{m}$-thick sections were immunostained for N-cadherin $(N$-cad; $B$, $D, F, H, K$ ) and counterstained with the nuclear dye Hoechst 33258 (Hoechst; $A, C, E, G, I$ ). Embryos were injected with antibody NCD-2 at stage 24 (E4) and allowed to survive for different lengths of time $(8 \mathrm{hr}, A, B ; 12 \mathrm{hr}, C, D ; 16 \mathrm{hr} E, F ; 20 \mathrm{hr}, G, H ; 24 \mathrm{hr}, I, K)$. Note that in some cases, a fusion of the two opposing diencephalic walls is seen $(G, H)$. Arrowheads point to the cell-sparse area of zona limitans intrathalamica at the border between the ventral thalamus ( $v t$ in $A$ ) and the dorsal thalamus $(d t$ in $A$ ). The arrow in $K$ points to the center of a rosette. $c$, Caudal; $r$, rostral. Scale bar, $0.2 \mathrm{~mm}$. 
thalamus, the ventral thalamus and the pretectum show no or only minor morphological changes. Interestingly, another member of the cadherin family, R-cadherin, is strongly and uniformly expressed by cells in the ventricular layer of the ventral thalamus and pretectum (Fig. 3C,D) (Gänzler and Redies, 1995). In the dorsal thalamus, only a few dispersed R-cadherin-positive cells were found in the ventricular layer. All other regions of the forebrain and midbrain showing high levels of generalized $\mathrm{R}$-cadherin mRNA expression in the ventricular layer at E4 were also unaffected by $\mathrm{N}$-cadherin blockage. These regions include parts of the telencephalon, the telencephalic-diencephalic transition zone, the epithalamus, the region of the optic recess, and the basal midbrain (Gänzler and Redies, 1995). Some additional areas devoid of R-cadherin expression in the ventricular layer were also unaffected by $\mathrm{N}$-cadherin blockage (data not shown).

In general, the rosettes observed in the dorsal thalamus have a layered structure similar to the rosettes in the tectum (data not shown). Gbx-2 expression, which is restricted to the mantle layer of the dorsal thalamus in control brains (Fig. $3 E$ ), is also found at the ventricular surface in $\mathrm{N}$-cadherin-blocked brains (Fig. $3 F$ ), suggesting the presence of mantle layer tissue at a ventricular location.

\section{Time course of morphological changes in the dorsal thalamus}

The morphological changes observed in the dorsal thalamus gradually appear during the first $24 \mathrm{hr}$ after antibody injection. The time course of the changes is depicted in Figure 4. At $4 \mathrm{hr}$ after injection, no changes could be observed (data not shown). At $8 \mathrm{hr}$, the $\mathrm{N}$-cadherin-expressing ependymal lining breaks up at several locations (Fig. 4B). Beginning at $12 \mathrm{hr}$, remnants of ependymal lining become displaced into the tissue of the neural tube. In several specimens, we observed a fusion of the diencephalic tissues from both sides of the brain in the midsagittal plane (Fig. $4 G, H)$. This fusion is restricted to those areas showing morphological changes in the neural tube wall and can persist to late developmental stages. In general, rosettes become a prominent feature at $\sim 20-24 \mathrm{hr}$. In the tectum, morphological changes occur later than in the diencephalon. At $20 \mathrm{hr}$, a breaking up of the ependymal lining can be observed. At $24 \mathrm{hr}$, rosettes are found.

\section{Morphological changes at later stages (E10-E11)}

To study possible late effect of the morphological changes induced by blocking $\mathrm{N}$-cadherin early in development, embryos were injected with antibodies at E4 and E5 and were allowed to develop until E10-E11. During normal development, the mantle layer of the tectum remains a layered structure, whereas the dorsal thalamus differentiates into a number of roundish cell aggregates (brain nuclei). After N-cadherin blockage, the histological architecture of both brain regions continues to be severely affected, as described in detail below. Although we cannot exclude the possibility that functionally blocking antibodies remain in brain tissue up to stage E10-E11, immunostaining for the injected blocking antibodies indicates that antibody concentration has decreased to low levels at late stages. No morphological changes were observed in brains injected with control antibodies.

\section{Tectum}

In brains treated with $\mathrm{N}$-cadherin antibodies, the centers of the rosettes formed by remnants of the ependymal lining can still be seen at E10-E11 (Fig. 5B, arrows). These ependymal centers express ZO-1 and N-cadherin (data not shown) and are arranged in a line located approximately in the middle of the tectal wall.
From this line to the pial surface, the layers of the tectum approximately resemble those of the control injected brains (layers I-X at E10; LaVail and Cowan, 1971) (Fig. 5A).

In addition to these layers, other layers are present between the ependymal centers and the ventricle. Although some of these additional layers appear disorganized, some other layers resemble normal tectal layers in their expression of specific molecular markers. For example, one of the layers located close to the ventricular surface contains loosely arranged, large multipolar $\mathrm{N}$-cadherin-expressing neurons (Fig. 5C, large arrowheads) reminiscent of those normally found in layer IV, the prospective stratum griseum centrale (Fig. 5A,C, small arrowheads). The innermost layer at the ventricular surface contains prominent fiber fascicles similar to those found in layer III, the prospective stratum album centrale, as revealed by $\mathrm{Ng}-\mathrm{CAM} / \mathrm{G} 4$ staining (data not shown). A subset of these fibers expresses axonin-1 (Fig. $5 D$, large arrowheads), a marker for a subpopulation of tectofugal neurites normally present in layer III (Yamagata et al., 1995). An ependymal lining is missing at the ventricular surface (Fig. 5, compare $A, B)$.

\section{Diencephalon}

The effects of early N-cadherin blockage on brain morphology at E10-E11 was also analyzed in the diencephalon. Consecutive sections were stained for Nissl substance and analyzed for cadherin expression. Representative results are shown in Figure $5 E-J$. R-cadherin is strongly expressed by the ependymal lining in the epithalamus and the dorsal thalamus at E10-E11 (Fig. 5G). Brains treated with $\mathrm{N}$-cadherin antibodies show a normal ependymal lining in the epithalamus, whereas in the dorsal thalamus the ependymal lining has disintegrated into small pieces distributed over the dorsal thalamic gray matter (Fig. 5J, arrows). The ventricular surface of this region lacks an ependymal lining. In the $\mathrm{N}$-cadherin-blocked brains, gray matter still develops in the dorsal thalamus (Fig. $5 H-J$ ) but is severely disorganized. Immunostaining with two markers for restricted dorsal thalamic regions, R-cadherin (Arndt and Redies, 1996) and cadherin-7, shows that gray matter structures expressing these markers are still present, but immunoreactive areas are fragmented and dispersed. Gray matter of the habenular area (epithalamus) and ventral thalamus assumes a more normal appearance.

\section{DISCUSSION}

The cell-cell adhesion molecule N-cadherin is ubiquitously expressed in the neuroepithelium of the developing chicken brain, with strongest expression in the ependymal lining. By injecting antibodies, we blocked the function of $\mathrm{N}$-cadherin at a period of development when gray matter structures begin to be formed in the mantle layer [4-5 d of incubation (E4-E5)]. Morphological effects of this blockage were studied by mapping the expression of various histological markers at early stages (approximately E6) and later stages (E10-E11). Results obtained in this study show that in specific brain regions, the integrity of the ependymal lining and the coherent epithelial structure of the neural tissue depend on $\mathrm{N}$-cadherin and are required for normal gray matter development in these areas.

\section{$\mathrm{N}$-cadherin blockage induces rosette formation}

$\mathrm{N}$-cadherin blockage results in a disruption of the sheet-like (epithelial) structure of the neural tube wall, followed by a folding in of smaller pieces of the neuroepithelium (rosettes). Similar results were obtained in cultures of early chicken retina, in which 

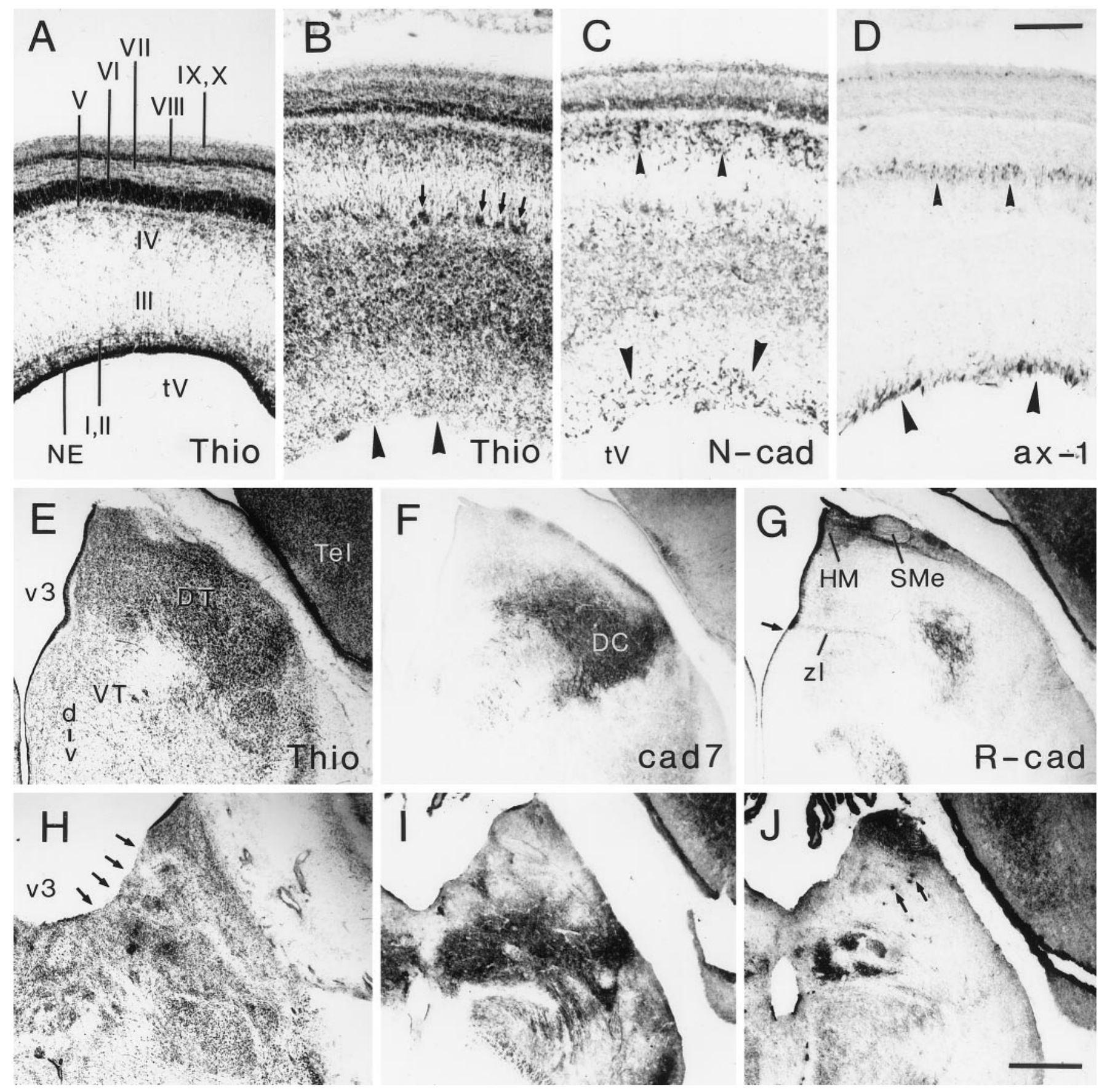

Figure 5. $A-D$, Late effects of N-cadherin blockage on tectal development. Sections through the tectum of an E10-E11 chicken embryo injected at E4 and E5 with control rat IgG $(A)$ or with a monoclonal antibody against N-cadherin $(B-D)$ are shown. Consecutive sections were stained for Nissl substance with thionine (Thio; $A, B)$, hybridized in situ with cRNA probe for N-cadherin $(N$-cad; $C)$, and immunostained with a monoclonal antibody against axonin-1 $(a x-1 ; D)$. Note the additional layers between remnants of the ependymal lining (arrows in $B$ ) and the ventricular surface of the NCD-2-injected brains. Small arrowheads in $C$ point to large multipolar N-cadherin-expressing ganglion cells reminiscent of those normally found in layer IV (Redies et al., 1993). In the NCD-2-injected brains, cells with a similar appearance are present in an additional layer close to the ventricle (large arrowheads in C). Small arrowheads in $D$ point to axonin-1 immunoreactivity reminiscent of that normally seen in layer III (Yamagata et al., 1995). Note that in addition, axonin-1 immunoreactivity can also be seen immediately below the ventricular surface of NCD-2-injected tecta (large arrowheads in $D$ ). The ventricular surface lacks an ependymal lining (large arrowheads in B). E-J, Late effects of N-cadherin blockage on the development of the dorsal thalamus. Frontal sections through the diencephalon from a noninjected E11 control embryo $(E-G)$ and from an E10-E11 embryo injected with monoclonal antibody NCD-2 against N-cadherin $(H-J)$ are shown. Consecutive sections were Nissl-stained with thionine (Thio; $E, H)$, or immunostained with antibodies against cadherin-7 (cad7; $F, I)$ and R-cadherin $(R$-cad; $G, J)$. The arrow in $G$ points to the border between the ventral thalamus $(V T$ in $E)$ and the dorsal thalamus $(D T$ in $E)$. This border is marked by the R-cadherin-positive zona limitans $(z l$ in $G)$ (Gänzler and Redies, 1995). The dorsal thalamus, but neither the habenular area of the epithalamus nor the ventral thalamus, is severely distorted by the antibodies against N-cadherin. Arrows in $J$ point to remnants of the ependymal lining, which is missing from most of the ventricular surface of the dorsal thalamus. Note that in the NCD-2-injected brains, gray matter is fragmented and fused at the midline in the dorsal thalamus. Like parts of the dorsal thalamic complex ( $D C$ in $F$ ), some of the fragments express cadherin-7 and R-cadherin. $d$, Dorsal; $H M$, nucleus habenularis medialis; $N E$, neuroepithelium; $S M e$, stria medullaris; Tel, telencephalon; $t V$, tectal ventricle; $v$, ventral; $v 3$, third ventricle; $I-X$, tectal layers at E10-E11 (LaVail and Cowan, 1971). Scale bars: $D, 0.1 \mathrm{~mm}(A-D) ; J, 0.5 \mathrm{~mm}(E-J)$. 


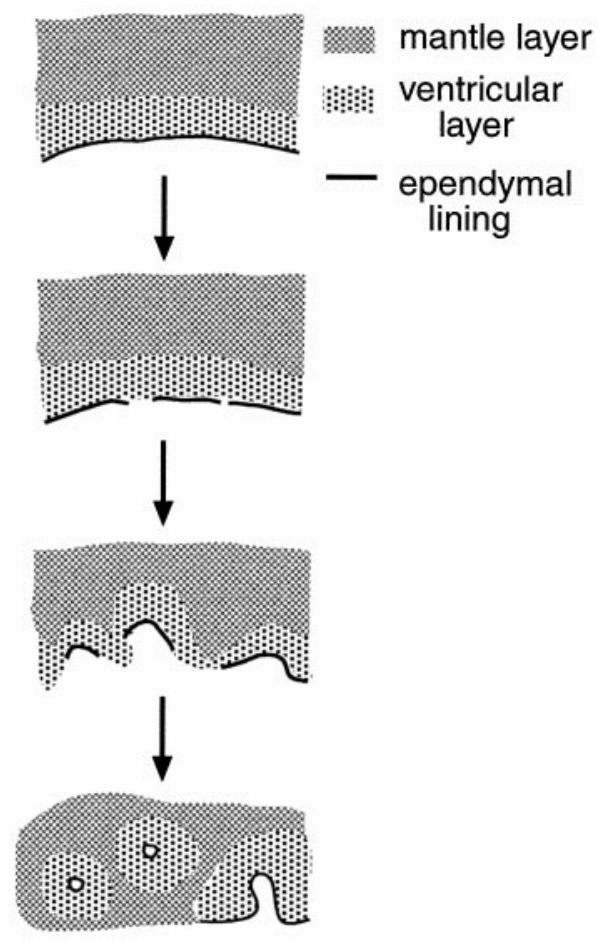

Figure 6. Schematic representation of rosette formation induced by $\mathrm{N}$-cadherin blockage. The top panel represents the normal neuroepithelium, and the three bottom panels represent different time points after antibody injection. Rosette formation starts with a breaking up of the ventricular lining, followed by a folding in of parts of the neuroepithelium, finally resulting in complete rosettes of neuroepithelial tissue. Rosettes are composed of ependymal lining in their centers (solid lines) surrounded by an inner "ventricular" layer of proliferating cells and an outer "mantle" layer of postmitotic neurons (shading).

rosettes of photoreceptor cells are induced by N-cadherin blockage (Matsunaga et al., 1988b). Rosette formation in the early retina has also been observed after inhibition of DNA synthesis and cell proliferation with cytosine-arabinoside (Liu et al., 1986). In the tectum, no rosette formation was reported when $\mathrm{N}$-cadherin was blocked at relatively late stages of development (Inoue and Sanes, 1997). It is possible that the undulation of the early embryonic neural tube observed in N-cadherin-deficient mice (Radice et al., 1997) and in chicken injected with functionally blocking antibodies against $\mathrm{N}$-cadherin (Bronner-Fraser et al., 1992; Nakagawa and Takeichi, 1997) relates to the epithelial disorganization described in the present study.

Figure 6 schematically summarizes the developmental time course of rosette formation from E4 to E6 (compare with Fig. 4). As a consequence of the tissue rearrangement, some mantle layer was found at the ventricular surface and pieces of ependymal lining in the middle of the neural tube wall. In the rosettes, the basic layering of the neural tube (inner ventricular layer and outer mantle layer) is preserved. The time course of the morphological changes suggests that the disruption of the ependymal lining is a first step in the formation of the rosettes. The ependymal lining shows the highest levels of N-cadherin expression, and it is located at the center of the rosettes. The surrounding regions (ventricular and mantle layer) express lower amounts of $\mathrm{N}$-cadherin. This finding is reminiscent of results from cell culture experiments showing that cells expressing high amounts of a particular cadherin form an inner core surrounded by cells ex-

\section{Control N-cadherin blockage}
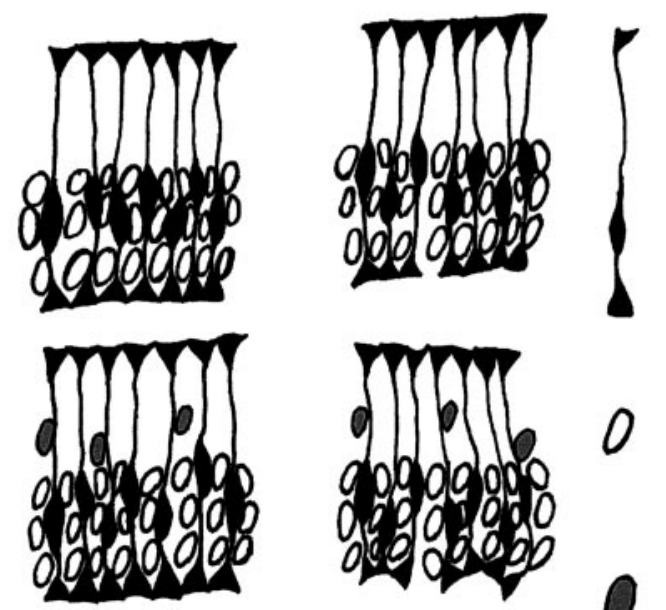

radial glia
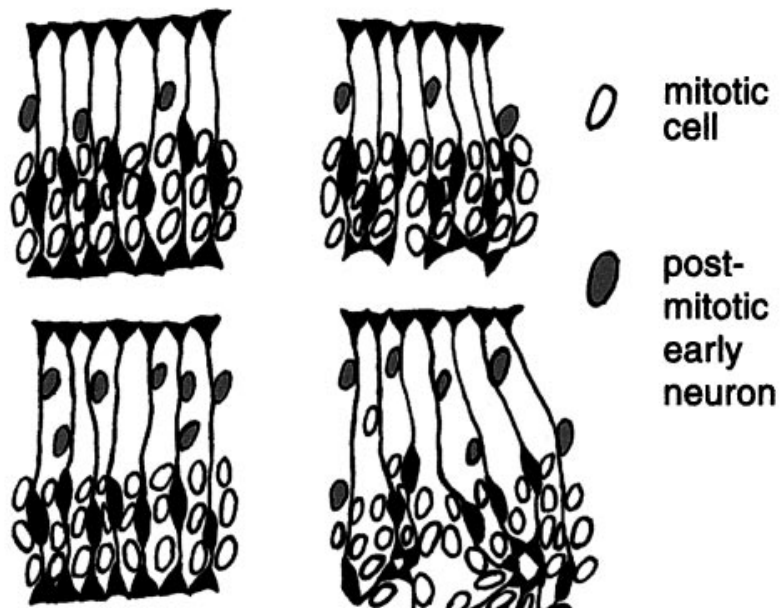

postmitotic early neuron

Figure 7. Hypothetical model to explain early and late morphological changes attributable to $\mathrm{N}$-cadherin blockage. In control brains, neural precursor cells (mitotic cells) proliferate in the ventricular layer. Postmitotic early neurons migrate outward into the mantle layer, presumably along radial glia processes. The end feet of the neuroepithelial cells are tightly connected to each other by $\mathrm{N}$-cadherin-associated adherens junctions, forming the ependymal lining. After $\mathrm{N}$-cadherin blockage, these junctions break up in susceptible regions (see Discussion). Remnants of intact ependymal lining round up and are drawn into the neural tube wall. They become surrounded by proliferating cells. Radial glial processes extend in all directions. Newly generated neurons use these cues to migrate outward in all directions including to the ventricular surface. Consequently, extra gray matter layers are deposited in the vicinity of the ventricle, as seen in the tectum. In the dorsal thalamus, newly generated neurons that normally migrate into the same approximate area of the mantle layer are now also misguided into other directions and aggregate in smaller gray matter fragments.

pressing lower amounts of the same molecule (Steinberg and Takeichi, 1994).

Formation of spherical structures from coherent epithelial tissues (or tubes) after inactivation of cadherin function has also been described in other systems. In the Drosophila E-cadherin mutant shotgun, the formation of spherical structures predominantly occurs in tissues showing a high degree of morphogenetic activity, such as the developing tracheal network and the Malpighian tubules (Tepass et al., 1996; Uemura et al., 1996). Reduced morphogenetic activity by the generation of double mutants leads to a rescue of the shotgun phenotype (Tepass et al., 1996). These findings suggested that zygotic E-cadherin is required for rearrangement processes of epithelial cells, whereas 
static epithelial architecture is preserved by a maternal pool of functional E-cadherin. In our experiments, $\mathrm{N}$-cadherin function was blocked at a time of development when the neuroepithelium undergoes massive cellular rearrangement by proliferation of precursor cells and migration of early neurons. Although the effect of N-cadherin blockage on static cell-cell junctions may be minor, the coherence of the neuroepithelial tissue may be lost in areas of dynamic cellular rearrangement. Such a differential effect may explain why the ependymal lining does not break down entirely but becomes fragmented at many individual points in the affected brain regions.

\section{Rosette formation is restricted to specific brain regions}

Rosettes are not formed in all brain regions at the same strength. For example, in the diencephalon the dorsal thalamus is severely affected, whereas the adjacent brain regions show little or no change. Interestingly, the affected area corresponds to a neuromeric brain subdivision (Rendahl, 1924; Puelles et al., 1987; Figdor and Stern, 1993; Puelles and Rubenstein, 1993), as visualized by its expression of Gbx-2 (Fig. $3 E, F$ ), a marker for the alar region of the dorsal thalamus (Bulfone et al., 1993). Visualization of the injected antibodies showed a relatively even diffusion into all diencephalic areas, ruling out that selective diffusion of antibody caused the region-specific effects observed. Differences in morphogenetic rearrangement processes between the diencephalic subdivisions are also an unlikely cause for the regional effects observed, because all diencephalic regions undergo similar processes of growth, migration, and differentiation during N-cadherin blockage (E4-E6) (Rendahl, 1924; Puelles et al., 1991).

$\mathrm{N}$-cadherin expression is relatively uniform throughout the neuroepithelium. We have reported previously that other cadherins are expressed in particular neuromeric subdivisions in the chicken brain (Gänzler and Redies, 1995; for review, see Redies and Takeichi, 1996; Fushimi et al., 1997). For example, $\mathrm{R}$-cadherin is expressed at high levels by most neuroepithelial cells throughout the ventral thalamus at E4-E6, whereas no or little expression is observed in the dorsal thalamus. Between E4 and E6, R-cadherin message is also found in the neuroepithelium of the pretectal area (Fig. 3C,D) (Fushimi et al., 1997) and of other forebrain and midbrain regions. All of these regions exhibit little or no changes after $\mathrm{N}$-cadherin blockage. Conceivably, $\mathrm{R}$-cadherin maintains the neuroepithelial structure in these brain regions. There are also unaffected brain areas that do not express R-cadherin, suggesting that other cadherins (or other adhesion molecules) may also substitute for $\mathrm{N}$-cadherin. In the affected regions, such a redundancy may be missing.

\section{$\mathrm{N}$-cadherin blockage can induce fusion of the two opposing diencephalic brain walls}

In several cases, a fusion of the two opposing diencephalic walls was observed. In the thalamus and pretectal area, this fusion is restricted to the dorsal thalamus. A possible reason for this fusion may be the closeness of the two opposing brain walls in this region and the translocation of mantle layer tissue to the ventricular surface. Differentiating cells in the mantle layer may be more prone to adhere to and mix with cells from the other side of the brain than the neuroepithelial cells that form a tightly adherent ependymal lining at the ventricular surface.

\section{$\mathrm{N}$-cadherin blockage induces additional tectal layers and disorganization of diencephalic gray matter}

The morphological effects observed at E10-E11 are probably the result of the changes induced by $\mathrm{N}$-cadherin blockage earlier in development rather than of a continued blockage of $\mathrm{N}$-cadherin, because antibody concentrations in neural tissue greatly diminish after the last injection at E5. In tecta treated with $\mathrm{N}$-cadherin antibody, the upper tectal layers assume an almost normal appearance. Some additional tectal layers seem to have formed at the ventricle. These layers are partially disorganized, but some resemble normal tectal layers in their expression of specific molecular markers (Fig. 5A-D). A cell-dense neuroepithelium and an ependymal lining is missing from the ventricular surface; ependymal remnants are found dispersed in the dorsal thalamus. A hypothetical model giving an explanation for these changes is depicted in Figure 7. In this model, early neurons that normally migrate toward the pial surface along processes of radial glia or by perikaryal translocation (Fig. 7, left panel) (Domesick and Morest, 1977; Snow and Robson, 1995) are misguided into all directions (also toward the ventricular surface) because of the rosettelike rearrangement of the neuroepithelium (Fig. 7, right panel). Misguiding of neurons into abnormal directions may also be the reason for the disorganization of dorsal thalamic gray matter. Cohorts of neurons that normally end up in a similar position now become widely dispersed. As a consequence, only subpopulations of the neurons destined to form a particular gray matter region aggregate. Some of the resulting gray matter fragments express R-cadherin and cadherin-7, two markers for restricted dorsal thalamic regions (Fig. 5E-J).

\section{REFERENCES}

Aaku-Saraste E, Hellwig A, Huttner WB (1996) Loss of occludin and functional tight junctions, but not $\mathrm{ZO}-1$, during neural tube closureremodeling of the neuroepithelium prior to neurogenesis. Dev Biol 180:664-679.

Arndt K, Redies C (1996) Restricted expression of R-cadherin by brain nuclei and neural circuits of the developing chicken brain. J Comp Neurol 373:373-399.

Auerbach R, Kubai L, Knighton D, Folkman J (1974) A simple procedure for the long-term cultivation of chicken embryos. Dev Biol 41:391-394.

Barami K, Kirschenbaum B, Lemmon V, Goldman SA (1994) $\mathrm{N}$-cadherin and $\mathrm{Ng}-\mathrm{Cam} / 8 \mathrm{D} 9$ are involved serially in the migration of newly generated neurons into the adult songbird brain. Neuron 13:567-582.

Bitzur S, Kam Z, Geiger B (1994) Structure and distribution of $\mathrm{N}$-cadherin in developing zebra fish embryos: morphogenetic effects of ectopic over-expression. Dev Dyn 201:121-136.

Bixby JL, Zhang R (1990) Purified N-cadherin is a potent substrate for the rapid induction of neurite outgrowth. J Cell Biol 110:1253-1260.

Bixby JL, Lilien J, Reichardt LF (1988) Identification of the major proteins that promote neuronal process outgrowth on Schwann cells in vitro. J Cell Biol 107:353-361.

Bronner-Fraser M, Wolf JJ, Murray BA (1992) Effects of antibodies against N-cadherin and N-CAM on the cranial neural crest and neural tube. Dev Biol 153:291-301.

Bulfone A, Puelles L, Porteus MH, Frohmann MA, Martin GR, Rubenstein JLR (1993) Spatially restricted expression of Dlx-1, Dlx-2 (Tes1), Gbx-2, and Wnt-3 in the embryonic day 12.5 mouse forebrain defines potential transverse and longitudinal segmental boundaries. J Neurosci 13:3155-3172.

Chapman G, Rathjen PD (1995) Sequence and evolutionary conservation of the murine Gbx-2 homeobox gene. FEBS Lett 364:289-292.

Crossin KL, Chuong C-M, Edelman GM (1985) Expression sequences of cell adhesion molecules. Proc Natl Acad Sci USA 82:6942-6946.

de la Rosa EJ, Kayyem JF, Roman JM, Stierhof Y-D, Dreyer WJ, Schwarz U (1990) Topologically restricted appearance in the developing chick retinotectal system of Bravo, a neural surface protein: experimental modulation by environmental cues. J Cell Biol 111:3087-3096. 
Detrick RJ, Dickey D, Kintner CR (1990) The effects of N-cadherin misexpression on morphogenesis in Xenopus embryos. Neuron 4:493-506.

Domesick VB, Morest DK (1977) Migration and differentiation of ganglion cells in the optic tectum of the chick embryo. Neuroscience 2:459-475.

Dräger UC, Edwards DL, Barnstable CJ (1984) Antibodies against filamentous components in discrete cell types of the mouse retina. J Neurosci 4:2025-2042.

Duband J-L, Volberg T, Sabanay I, Thiery JP, Geiger B (1988) Spatial and temporal distribution of the adherens-junction-associated adhesion molecule A-CAM during avian embryogenesis. Development 103:325-344

Fannon AM, Colman DR (1996) A model for central synaptic junctional complex formation based on the differential adhesive specifities of the cadherins. Neuron 17:423-434.

Figdor MC, Stern CD (1993) Segmental organization of embryonic diencephalon. Nature 363:630-634.

Fujimori T, Miyatani S, Takeichi M (1990) Ectopic expression of $\mathrm{N}$-cadherin perturbs histogenesis in Xenopus embryos. Development 110:97-104.

Fushimi D, Arndt K, Takeichi M, Redies C (1997) Cloning and expression analysis of cadherin-10 in the CNS of the chicken embryo. Dev Dyn 209:269-285.

Gänzler SI, Redies C (1995) R-cadherin expression during nucleus formation in chicken forebrain neuromeres. J Neurosci 15:4157-4172.

Gänzler SI, Redies C (1996) Effect of N-cadherin antibodies on histogenesis of the early developing chicken brain. Soc Neurosci Abstr 22:990.

Hamburger V, Hamilton HL (1951) A series of normal stages in the development of the chick embryo. J Morphol 88:49-92.

Hatta K, Takeichi M (1986) Expression of N-cadherin adhesion molecules associated with early morphogenetic events in chick development. Nature 320:447-449.

Hatta K, Nose A, Nagafuchi A, Takeichi M (1988) Cloning and expression of cDNA encoding a neural calcium-dependent cell adhesion molecule: its identity in the cadherin gene family. J Cell Biol 106:873-881.

Herman J-P, Victor JC, Sanes JR (1993) Developmentally regulated and spatially restricted antigens of radial glial cells. Dev Dyn 197:307-318.

Inoue A, Sanes JR (1997) Lamina-specific connectivity in the brain: regulation by N-cadherin, neurotrophins, and glycoconjugates. Science 276:1428-1431.

Inuzuka H, Miyatani S, Takeichi M (1991) R-cadherin: a novel $\mathrm{Ca}^{2+}$ dependent cell-cell adhesion molecule expressed in the retina. Neuron 7:69-79.

Itoh M, Yonemura S, Nagafuchi A, Tsukita S, Tsukita S (1991) A 220 kDa undercoat-constitutive protein: its specific localization at cadherinbased cell-cell adhesion sites. J Cell Biol 115:1449-1462.

Itoh M, Nagafuchi A, Yonemura S, Kitani-Yasuda T, Tsukita S, Tsukita $\mathrm{S}$ (1993) The $220 \mathrm{kDa}$ protein colocalizing with cadherins in nonepithelial cells is identical to ZO-1, a tight junction-associated protein in epithelial cells: cDNA cloning and immunoelectron microscopy. J Cell Biol 121:491-502.

Iwai Y, Usui T, Hirano S, Steward R, Takeichi M, Uemura T (1997) Axon patterning requires $D \mathrm{~N}$-cadherin, a novel neuronal adhesion receptor, in the Drosophila embryonic CNS. Neuron 19:77-89.

LaVail JH, Cowan WM (1971) The development of the chick optic tectum. I. Normal morphology and cytoarchitectonic development. Brain Res 28:391-419.

Liaw CW, Cannon C, Power MD, Kiboneka PK, Rubin LL (1990) Identification and cloning of two species of cadherins in bovine endothelial cells. EMBO J 9:2701-2708.

Liu L, Halfter W, Layer PG (1986) Inhibition of cell proliferation by cytosin-arabinoside and its interference with spatial and temporal differentiation patterns in the chick retina. Cell Tissue Res 244:501-513.

Matsunaga M, Hatta K, Nagafuchi A, Takeichi M (1988a) Guidance of optic nerve fibers by $\mathrm{N}$-cadherin adhesion molecules. Nature 334:62-64.

Matsunaga M, Hatta K, Takeichi M (1988b) Role of N-cadherin cell adhesion molecules in the histogenesis of neural retina. Neuron 1:289-295.

Nakagawa S, Takeichi M (1997) N-cadherin is crucial for heart formation in the chick embryo. Dev Growth Differ 39:451-455.
Puelles L, Rubenstein JLR (1993) Expression patterns of homeobox and other putative regulatory genes in the embryonic mouse forebrain suggest a neuromeric organization. Trends Neurosci 16:472-479.

Puelles L, Amat JA, Martinez-de-la-Torre M (1987) Segment-related, mosaic neurogenetic pattern in the forebrain and mesencephalon of early chick embryos. I. Topography of AChE-positive neuroblasts up to stage HH18. J Comp Neurol 266:247-268.

Puelles L, Guillén M, Martínez-de-la-Torre M (1991) Observations on the fate of nucleus superficialis magnocellularis of Rendahl in the avian diencephalon, bearing on the organization and nomenclature of neighboring retinorecipient nuclei. Anat Embryol 183:221-233.

Radice GL, Rayburn H, Matsunami H, Knudsen KA, Takeichi M, Hynes RO (1997) Developmental defects in mouse embryos lacking N-cadherin. Dev Biol 181:64-78.

Redies C, Takeichi M (1993) Expression of N-cadherin mRNA during development of the mouse brain. Dev Dyn 197:26-39.

Redies C, Takeichi M (1996) Cadherins in the developing central nervous system: an adhesive code for segmental and functional subdivisions. Dev Biol 180:413-423.

Redies C, Inuzuka H, Takeichi M (1992) Restricted expression of N- and R-cadherin on neurites of the developing chicken CNS. J Neurosci 12:3525-3534.

Redies C, Engelhart K, Takeichi M (1993) Differential expression of Nand R-cadherin in functional neuronal systems and other structures of the developing chicken brain. J Comp Neurol 333:398-416.

Redies C, Arndt K, Ast M (1997) Expression of the cell adhesion molecule axonin-1 in neuromeres of the chicken diencephalon. J Comp Neurol 381:230-252.

Rendahl H (1924) Embryologische und morphologische Studien über das Zwischenhirn beim Huhn. Acta Zool (Stockh) 5:241-344.

Riehl R, Johnson K, Bradley R, Grunwald GB, Cornel E, Lilienbaum A, Holt CE (1996) Cadherin function is required for axon outgrowth in retinal ganglion cells in vivo. Neuron 17:837-848.

Salomon D, Ayalon O, Patel-King R, Hynes RO, Geiger B (1992) Extrajunctional distribution of $\mathrm{N}$-cadherin in cultured human endothelial cells. J Cell Sci 102:7-17.

Snow RL, Robson JA (1995) Migration and differentiation of neurons in the retina and optic tectum of the chick. Exp Neurol 134:13-24.

Steinberg MS, Takeichi M (1994) Experimental specification of cell sorting, tissue spreading, and specific spatial patterning by quantitative differences in cadherin expression. Proc Natl Acad Sci USA 91:206-209.

Stone KE, Sakaguchi DS (1996) Pertubation of the developing Xenopus retinotectal projection following injections of antibodies against $\beta 1$ integrin receptors and N-cadherin. Dev Biol 180:297-310.

Tepass U, Gruszynski-DeFeo E, Haag TA, Omatyar L, Török T, Hartenstein V (1996) Shotgun encodes Drosophila E-cadherin and is preferentially required during cell rearrangement in the neurectoderm and other morphogenetically active epithelia. Genes Dev 10:672-685.

Thanos S, Bonhoeffer F (1983) Investigations on the development and topographic order of retinotectal axons: anterograde and retrograde staining of axons and perikarya with rhodamine in vivo. J Comp Neurol 219:420-430.

Tomaselli KJ, Neugebauer KM, Bixby JL, Lilien J, Reichardt LF (1988) $\mathrm{N}$-cadherin and integrins: two receptor systems that mediate neuronal process outgrowth on astrocyte surfaces. Neuron 1:33-43.

Uchida N, Honjo Y, Johnson KR, Wheelock MJ, Takeichi M (1996) The catenin/cadherin adhesion system is localized in synaptic junctions bordering transmitter release zones. J Cell Biol 135:767-779.

Uemura T, Oda H, Kraut R, Hayashi S, Kataoka Y, Takeichi M (1996) Zygotic Drosophila E-cadherin expression is required for processes of dynamic epithelial cell rearrangement in the Drosophila embryo. Genes Dev 10:659-671.

Vanselow J, Thanos S, Godement P, Henke-Fahle S, Bonhoeffer F (1989) Spatial arrangement of radial glia and ingrowing retinal axons in the chick optic tectum during development. Dev Brain Res 45:15-27.

Volk T, Geiger B (1986) A-CAM: a $135 \mathrm{kDa}$ receptor of intercellular adherens junctions. II. Antibody-mediated modulation of junction formation. J Cell Biol 103:1451-1464.

Yamagata M, Herman J-P, Sanes JR (1995) Lamina-specific expression of adhesion molecules in developing chick optic tectum. J Neurosci 15: 4556-4571. 